OPEN ACCESS

Edited by:

Karen A. Stockin,

Massey University, New Zealand

Reviewed by:

Nakita Câmara,

University of Las Palmas de Gran

Canaria, Spain

Emma Betty,

Massey University, New Zealand

${ }^{*}$ Correspondence:

Wei-Cheng Yang

yangweicheng@g.ntu.edu.tw

Specialty section:

This article was submitted to

Marine Megafauna,

a section of the journal

Frontiers in Marine Science

Received: 15 September 2020

Accepted: 26 May 2021

Published: 18 June 2021

Citation:

Li W-T, Chou L-S, Chiou H-Y, Chen I-H and Yang W-C (2021) Analyzing 13 Years of Cetacean

Strandings: Multiple Stressors to Cetaceans in Taiwanese Waters and Their Implications

for Conservation and Future

Research. Front. Mar. Sci. 8:606722. doi: 10.3389/fmars.2021.606722

\section{Analyzing 13 Years of Cetacean Strandings: Multiple Stressors to Cetaceans in Taiwanese Waters and Their Implications for Conservation and Future Research}

\author{
Wen-Ta Li',2, Lien-Siang Chou ${ }^{3}$, Hue-Ying Chiou ${ }^{4}$, I-Hua Chen ${ }^{5}$ and Wei-Cheng Yang ${ }^{1 *}$ \\ ${ }^{1}$ School of Veterinary Medicine, National Taiwan University, Taipei, Taiwan, ${ }^{2}$ Pangolin International Biomedical Consultant \\ Ltd., Keelung, Taiwan, ${ }^{3}$ Institute of Ecology and Evolutionary Biology, National Taiwan University, Taipei, Taiwan, ${ }^{4}$ Graduate \\ Institute of Veterinary Pathobiology, National Chung Hsing University, Taichung, Taiwan, ${ }^{5}$ Department of Veterinary Medicine, \\ National Chiayi University, Chiayi City, Taiwan
}

This study summarizes the postmortem investigations of 73 cetaceans stranded on the coast of Taiwan between 2001 and 2013, including 51 Delphinidae, 17 Kogiidae, 3 Ziphiidae, 1 Physeteridae, and 1 Balaenopteridae. Of these, eight (11\%) were categorized into direct human-related strandings, including fisheries interaction (bycatch), vessel collision and other anthropogenic-related pathology. Gastrointestinal foreign bodies were found in eight individuals (11\%). Most of the bacteria isolated from stranded dolphins were zoonotic pathogens including extended-spectrum $\beta$-lactamases Escherichia coli, which indicates waste pollution from land. Severe parasite infestation was found in 36 of the cases (49\%), which suggests that the immune function could be compromised. Thirty-eight cases (52\%) were diagnosed with myocardial patchy fibrosis or dilated cardiomyopathy. The evidence shown here indicates that cetaceans around Taiwanese waters may suffer from multiple stressors. This study provides baseline data for the health assessment of cetacean populations in Taiwan, which may ultimately provide recommendations for future cetacean conservation and research throughout the western Pacific.

\section{Keywords: bycatch, disease, health assessment, stranded cetaceans, stressors, pathology, pollution}

\section{INTRODUCTION}

Health assessments enable us to better understand the diseases, pathogens, and anthropogenic impacts that affect cetaceans, and thereby provide recommendations for cetacean conservation (McFee and Lipscomb, 2009; Bogomolni et al., 2010; Arbelo et al., 2013). Such health assessments could be conducted by capture-release examination of cetaceans at sea (Wells et al., 2005; Miller et al., 2011; Schwacke et al., 2014), or postmortem examination of stranded cetaceans (Cornaglia et al., 2000; Parsons and Jefferson, 2000; McFee and Lipscomb, 2009; Bogomolni et al., 2010; Arbelo et al., 2013; Diaz-Delgado et al., 2018). Using the capture-release examination method, samples are obtained from randomly selected individuals, and may represent wild populations (Reddy et al., 2001). However, the application of the capture-release method is limited by several 
factors, including body size and behavior of targeted species, types of coastal landform, logistical support, and examination methods (Hunt et al., 2013). Thus, the capture-release method could be impractical in some situations. In contrast, postmortem investigation of stranded cetaceans could provide an opportunity to carry out detailed sample collections and examinations during necropsy or rehabilitation, enabling disease detection in otherwise inaccessible wild populations (Reddy et al., 2001). For example, some infectious diseases, such as brucellosis and toxoplasmosis, were first identified from stranded cetaceans (Inskeep et al., 1990; Ross et al., 1994). A previous study on pathologic findings of stranded cetaceans identified that human activity was directly responsible for 19\% of cetacean deaths (DiazDelgado et al., 2018). Therefore, postmortem investigation of stranded cetaceans can provide an insight into the health status of cetacean populations.

Several previous studies have conducted health assessments on stranded cetaceans (Bonar et al., 2007; Forman et al., 2009; McFee and Lipscomb, 2009; Bogomolni et al., 2010; Arbelo et al., 2013; Sierra et al., 2014; Diaz-Delgado et al., 2018), which can be categorized into specific etiology-based and pathology-based investigations according to the aim of the research. Specific etiology-based investigations primarily used serology and polymerase chain reaction (PCR) to examine target infectious diseases in marine mammals. For example, a previous study focused on the detection of Toxoplasma gondii infection on stranded cetaceans by serological method (Forman et al., 2009), and another study utilized immunohistochemical (IHC) staining and PCR to detect the etiology causing nonsuppurative meningoencephalitis in stranded cetaceans (Sierra et al., 2014). Pathology-based investigation provides fundamental information on cetacean diseases, and enables us to categorize causes of stranding/death in stranded cetaceans. The causes of death can be categorized into (a) anthropogenic origin, which includes foreign body, vessel collision, fishery interaction, and military sonar; and (b) natural origin, which can be divided into neonatal pathology, infectious (bacterial, viral, parasitic, and fungal infection) and non-infectious diseases (such as emaciation or trauma) (McFee and Lipscomb, 2009; Arbelo et al., 2013). Another categorization presented by Bogomolni et al. (2010) was that the causes of death are divided into eight diagnostic fields via pathological examination, including disease, human-related, mass-stranding, single-stranded with no significant findings, rock and/or sand ingestion, predatory attack, failure to thrive or dependent calf or pup, or other. Systemic categorization of stranded cetaceans, based on detailed postmortem investigations, would facilitate analysis of the cause of stranding/death, and thereby inform future priorities for cetacean research and conservation.

According to the Taiwan cetacean stranding record (19942013), an average of 50 stranding events occur each year involving more than 30 species (Taiwan Cetacean Society Network) ${ }^{1}$. Although samples/data from stranded cetaceans have been consistently collected by stranding network, Taiwan Cetacean Society Network (TCSN), systematic postmortem investigation of

${ }^{1}$ http://tcsn.whale.org.tw/ stranded cetaceans in Taiwan is still lacking. The main objective of this study was to investigate disease and cause of death in cetaceans stranded on the Taiwanese coast over a 13-year period (2001-2013) through systematic pathology-based investigations, including hematology and bacteriology. In addition, the study aimed to provide baseline data for the health assessment of cetacean populations in Taiwan, which may ultimately provide recommendations for future cetacean conservation and research throughout the western Pacific.

\section{MATERIALS AND METHODS}

From 2001 to 2013, efforts were made to collect both liveand dead-stranded cetaceans along the coast of Taiwan. The decomposition levels of stranded animals or carcasses were described as: Code 1: live stranded; Code 2: fresh dead; Code 3: moderate autolysis; Code 4: advanced autolysis; and Code 5: mummified or skeletal remains (IJsseldijk et al., 2019). Codes were given to all stranded cetaceans, and only stranded cetaceans with code 1-3 were included in this study.

Systematic postmortem examinations and sample collection were performed following standard procedures (IJsseldijk et al., 2019). Samples for histopathology were systematically collected, preserved in $10 \%$ neutral buffered formalin, and then submitted for pathological diagnosis. Hematological and biochemical examinations were performed in live stranded cetaceans according to standard procedures (Bossart et al., 2001; Geraci and Lounsbury, 2005). In brief, blood samples were drawn from the caudal vascular bundle within the tail flukes, and collected in vacutainer tubes with ethylenediaminetetraacetic acid (EDTA) for hematological examinations, and tubes with sodium citrate and heparin for biochemical examination. Complete blood count (CBC) including red blood cell (RBC) parameters, total white blood cell (WBC) count, and WBC differential count was performed. The following serum analyte concentrations and enzyme activities were measured: (1) liver-associated serum enzymes including alanine aminotransferase (ALT), aspartate aminotransferase (AST), lactate dehydrogenase (LDH), alkaline phosphatase (ALKP), and gamma-glutamyltransferase $(\gamma$-GT); (2) kidney-associated serum analytes including blood urea nitrogen (BUN) and creatinine; (3) serum proteins including total protein, albumin, and globulin; (4) other serum analytes/enzyme activities including uric acid, total and indirect bilirubin, iron, total iron-binding capacity (TIBC), fibrinogen, and creatinine phosphokinase (CK); (5) electrolytes including sodium, potassium, chloride, calcium, phosphate, and magnesium. Furthermore, electrophoretic separation of $\mathrm{CK}$ isoenzymes, $\mathrm{LDH}$ isoenzymes, and serum proteins were performed to provide more specific information.

Bacteriological samples were collected following standard procedures (IJsseldijk et al., 2019). In brief, bacteriological samples of live stranded cetaceans were obtained from blowhole and/or lesion of body surface with appropriate transport media, and samples of fresh dead stranded cetaceans were obtained from lung, liver, spleen, kidney, and/or apparent lesions of viscera or body surface. The samples were sent to a clinical laboratory 
for bacterial culture, isolation, identification, and antimicrobial susceptibility test.

Causes of stranding and/or death were established according to the findings from the examinations mentioned above, and described as: (1) bacterial infection: meaningful bacteria isolated from blow hole and internal organs; (2) viral infection: macroscopic evidences of viral skin/mucosa lesions (black spots, tattoos, dark/white-fringed spots, vesicles, warts, and plaques) and microscopic evidences of viral lesions such as syncytial cells and/or inclusion bodies in dermal, pulmonary, neural, and other visceral tissues (Van Bressem et al., 1999; Raga et al., 2008; van Elk et al., 2009; Hart et al., 2012; Di Guardo et al., 2013; Figure 1A); (3) parasite infestation: low or high parasite loads in cranial sinus, aural peribullar cavity, respiratory tract, gastrointestinal tract, other visceral parenchyma, body cavity, and/or blubber (Figures 1B-D); (4) diseases of organ systems: cardiovascular, respiratory, gastrointestinal, hepatobiliary-pancreatic, urogenital, and central nervous system (CNS) abnormities or lesions

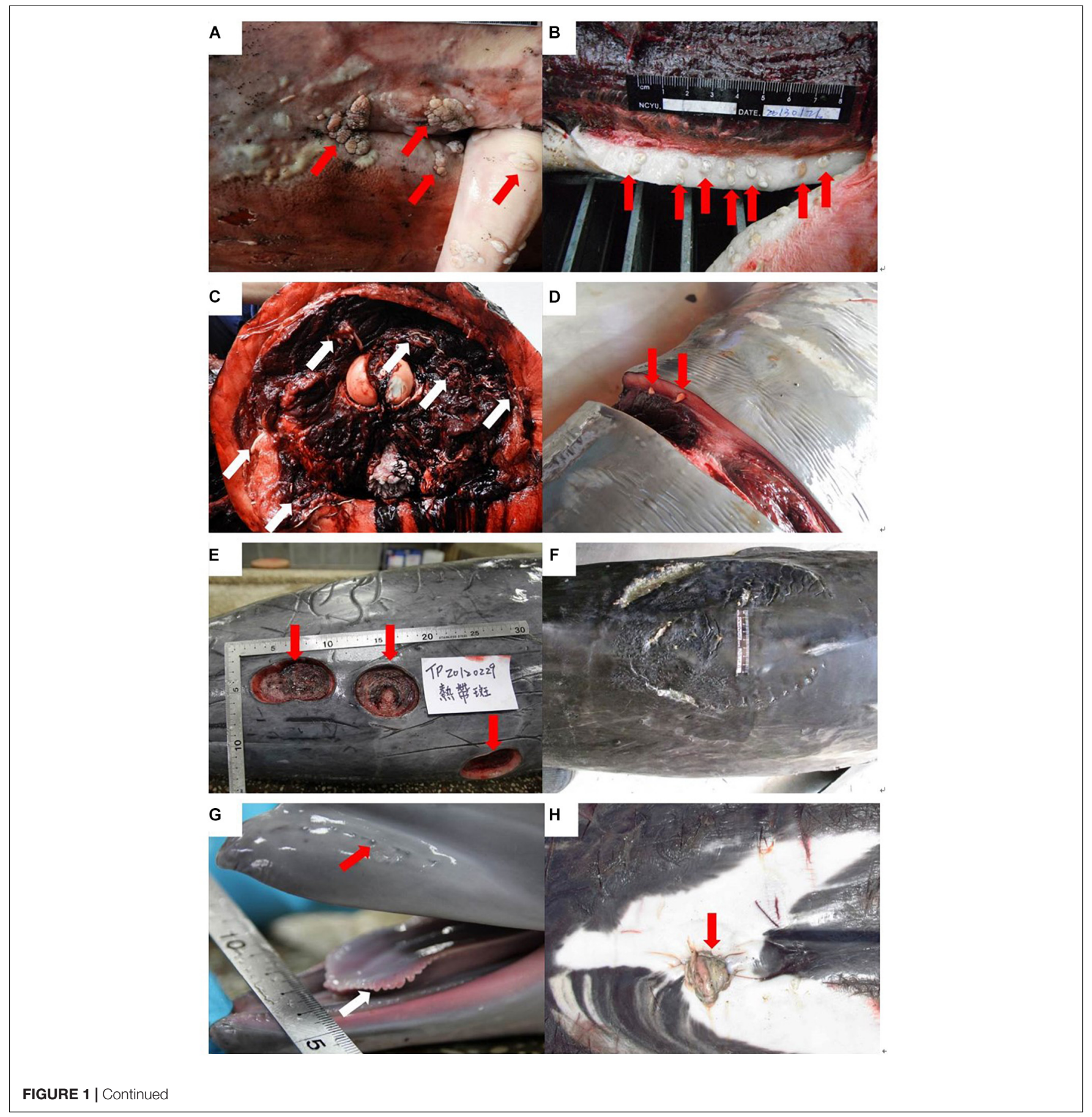




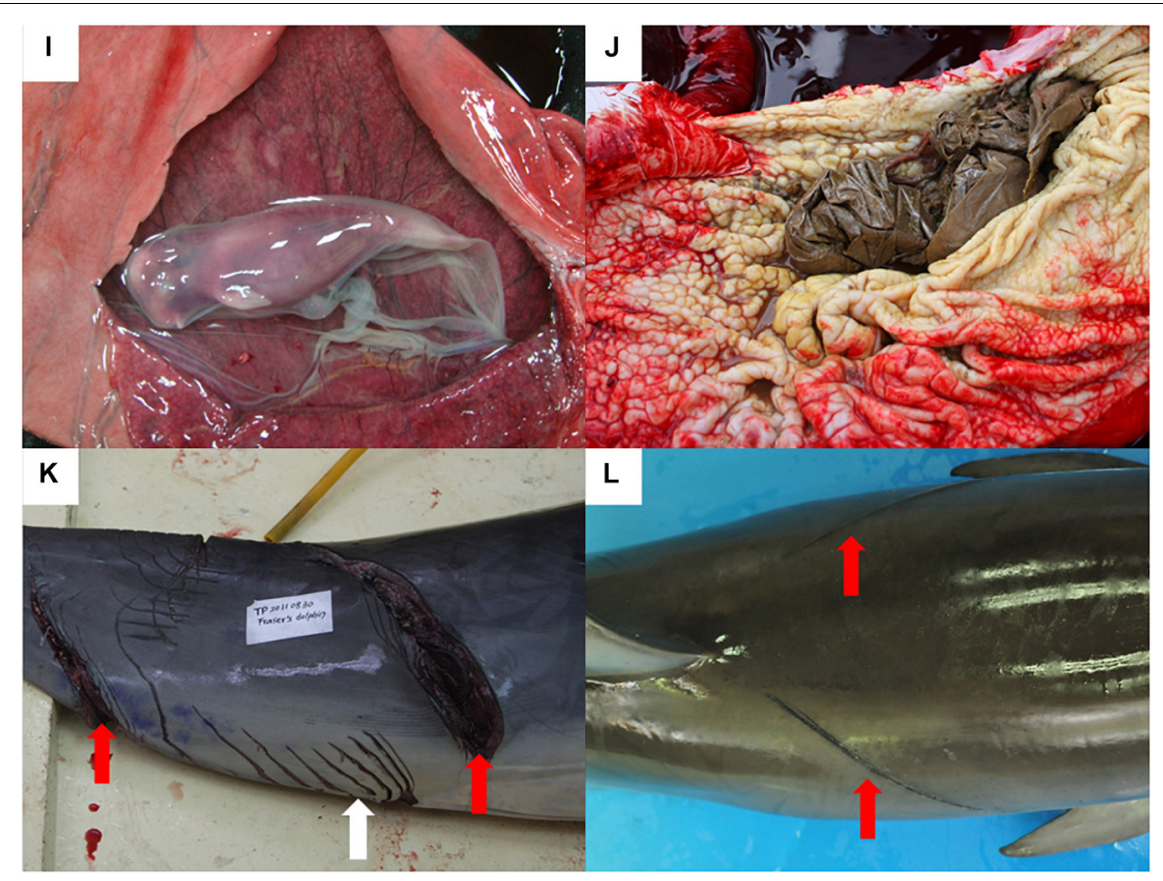

FIGURE 1 | Continued

Examples of descriptive terms in stranded cetaceans in Taiwan. Viral infection: warts/plaques on the mucosa of penis and genital opening (arrows) (A); parasite infestation: severe parasite infestation (arrows) (B,C) and mild parasite infestation (arrows) (D); shark attack: severe wounds caused by sharks (E,F); maternal separated calf: calf with hair follicles (red arrow) and marginal papillae (white arrow) (G); unhealed umbilical cord (red arrow) (H); pregnant individual: fetus in uterus of stranded cetacean (I); gastrointestinal foreign bodies: non-prey items in stomach (J); human-related traumas: sharp trauma (red arrows). White arrow: inter/intraspecific traumatic interactions (K); and linear impressions (red arrows) (L).

diagnosed via hematological, biochemical, and pathological examinations; (5) shark attack: individuals with severe shark bite wounds associated with the cause of death and/or stranding (Figures 1E,F), being defined in two types: (a) wounds on the body that are either crescent-shaped puncture marks from teeth or have deep and widely spaced tooth rakes (Parsons and Jefferson, 2000; Luksenburg, 2014); (b) relative-smaller and conical-shaped wounds [bite wound by cookie cutter shark (Isistius sp.)] (Dwyer and Visser, 2011; Luksenburg, 2014); (6) maternal separation of calf: single-stranded suckling calf characterized by hair follicles of rostrum, marginal papillae of the tongue, and umbilical cord (Figures 1G,H); (7) pregnant individual: fetus was found in stranded cetacean (Figure 1I); (8) gastrointestinal foreign bodies: non-prey items were found in gastrointestinal tract (Figure 1J); (9) direct human activityrelated: anthropogenic trauma such as linear impressions, sharp/blunt traumas, penetration wounds, subcutaneous/muscle hemorrhage, and bruises (Moore et al., 2013) that were identified and associated with the cause of death and/or stranding (Figures 1K,L).

\section{RESULTS}

In total, 73 cetaceans with decomposition code 1-3 (live, fresh dead, and moderate autolysis) were investigated between 2001 and 2013, including 18 species of 4 different families of cetaceans (Table 1). Due to logistical difficulties encountered during necropsy in some cases, there were variations in the number of animals analyzed in hematological, biochemical, bacteriological, and histopathological examinations. Blood samples for hematological and biochemical examinations were collected from 26 (36\%) live-stranded cetaceans. Bacteriological samples were collected from 38 cases (52\%), including 19 live-stranded individuals that died following attempted rescue, 4 released live-stranded individuals, and 15 beachcast individuals. Systematic pathological examination and histopathological sample collection were performed in 69 cases (95\%), including 53 beachcast individuals and 16 live-stranded individuals that subsequently died.

Bacteriological examination was performed in 38 individuals (52\%) with 27 different bacteria strains isolated from 31 individuals (42\%) (Figure 2). Out of the 27 bacteria strains, Aeromonas hydrophila was isolated from blowhole, lung, liver, kidney, and spleen, and was the most common bacteria (13/38, $34.2 \%)$. Other frequent isolates were Vibrio parahaemolyticus (5/38, 13.2\%), Escherichia coli $(5 / 38,13.2 \%)$, and Klebsiella pneumoniae ssp. pneumonia (4/38, 10.5\%). In addition, Erysipelothrix rhusiopathiae was isolated from one (1/38, 3\%) stranded common bottlenose dolphin (Tursiops truncatus) that presented cutaneous rhomboid-shaped plaques and mild endocarditis. Results of an antimicrobial susceptibility test indicated almost all isolated bacterial strains were susceptible to 
TABLE 1 | Stranded cetaceans of the present study in Taiwan from 2001 to 2013.

\begin{tabular}{|c|c|c|c|c|c|c|c|c|c|c|c|c|c|c|c|}
\hline $\begin{array}{l}\text { Descriptive terms } \\
\text { species }\end{array}$ & CD & RD & UD & GD & HPD & CNSD & BI & VI & Pal & SPal & SA & PI & MSC & GFBs & HR \\
\hline Balaenoptera omurai $(n=1)$ & $1 / 1$ & $1 / 1$ & $0 / 1$ & $1 / 1$ & $0 / 1$ & $1 / 1$ & $1 / 1$ & $0 / 1$ & $1 / 1$ & $0 / 1$ & $0 / 1$ & $0 / 1$ & $0 / 1$ & $0 / 1$ & $0 / 1$ \\
\hline Delphinus capensis $(n=1)$ & $1 / 1$ & $1 / 1$ & $0 / 1$ & $0 / 1$ & $1 / 1$ & $1 / 1$ & $0 / 1$ & $0 / 1$ & $1 / 1$ & $0 / 1$ & $0 / 1$ & $0 / 1$ & $0 / 1$ & $0 / 1$ & $0 / 1$ \\
\hline Feresa attenuata $(n=11)$ & $9 / 11$ & $10 / 11$ & $8 / 11$ & $4 / 11$ & $10 / 11$ & $0 / 5$ & $2 / 3$ & $0 / 11$ & $9 / 11$ & $4 / 11$ & $0 / 11$ & $0 / 11$ & $0 / 11$ & $0 / 11$ & $0 / 11$ \\
\hline Globicephala macrorhynchus $(n=6)$ & $6 / 6$ & $6 / 6$ & $1 / 6$ & $5 / 6$ & $1 / 6$ & $0 / 3$ & $1 / 1$ & $0 / 6$ & $6 / 6$ & $6 / 6$ & $0 / 6$ & $0 / 6$ & $0 / 6$ & $0 / 6$ & $0 / 6$ \\
\hline Grampus griseus $(n=4)$ & $4 / 4$ & $4 / 4$ & $1 / 4$ & $4 / 4$ & $4 / 4$ & $2 / 4$ & $3 / 4$ & $0 / 4$ & $4 / 4$ & $3 / 4$ & $0 / 4$ & $0 / 4$ & $0 / 4$ & $1 / 4$ & $0 / 4$ \\
\hline Kogia breviceps $(n=4)$ & $3 / 4$ & $2 / 4$ & $0 / 4$ & $3 / 4$ & $3 / 4$ & $1 / 2$ & $2 / 2$ & $0 / 4$ & $4 / 4$ & $3 / 4$ & $0 / 4$ & $1 / 4$ & $0 / 4$ & $1 / 4$ & $0 / 4$ \\
\hline Kogia sima $(n=13)$ & $12 / 13$ & $10 / 13$ & $0 / 13$ & $11 / 13$ & $8 / 13$ & $1 / 9$ & $8 / 11$ & $1 / 13$ & $12 / 13$ & $7 / 13$ & $0 / 13$ & $3 / 13$ & $0 / 13$ & $0 / 13$ & $0 / 13$ \\
\hline Lagenodelphis hosei $(n=8)$ & $5 / 8$ & $7 / 8$ & $0 / 8$ & $2 / 8$ & $4 / 8$ & $1 / 5$ & $4 / 4$ & $1 / 8$ & $5 / 8$ & $2 / 8$ & $0 / 8$ & $1 / 8$ & $2 / 8$ & $1 / 8$ & $4 / 8$ \\
\hline Mesoplodon densirostris $(n=2)$ & $2 / 2$ & $2 / 2$ & $2 / 2$ & $0 / 2$ & $1 / 2$ & N.A & N.A & $0 / 2$ & $2 / 2$ & $1 / 2$ & $0 / 2$ & $1 / 2$ & $0 / 2$ & $0 / 2$ & $1 / 2$ \\
\hline Peponocephala electra $(n=1)$ & $0 / 1$ & $1 / 1$ & $0 / 1$ & $1 / 1$ & $1 / 1$ & $0 / 1$ & $1 / 1$ & $0 / 1$ & $1 / 1$ & $1 / 1$ & $0 / 1$ & $0 / 1$ & $0 / 1$ & $1 / 1$ & $0 / 1$ \\
\hline Physeter macrocephalus ( $n=1)$ & $1 / 1$ & $0 / 1$ & $0 / 1$ & $1 / 1$ & $1 / 1$ & $0 / 1$ & $1 / 1$ & $0 / 1$ & $0 / 1$ & $0 / 1$ & $0 / 1$ & $0 / 1$ & $1 / 1$ & $0 / 1$ & $0 / 1$ \\
\hline Pseudorca crassidens $(n=1)$ & $0 / 1$ & $0 / 1$ & $0 / 1$ & $1 / 1$ & $0 / 1$ & N.A & N.A & $0 / 1$ & $0 / 1$ & $0 / 1$ & $0 / 1$ & $0 / 1$ & $0 / 1$ & $0 / 1$ & $0 / 1$ \\
\hline Sousa chinensis $(n=1)$ & $1 / 1$ & $1 / 1$ & $0 / 1$ & $0 / 1$ & $1 / 1$ & N.A & $1 / 1$ & $1 / 1$ & $0 / 1$ & $0 / 1$ & $0 / 1$ & $0 / 1$ & $0 / 1$ & $0 / 1$ & $1 / 1$ \\
\hline Stenella attenuata $(n=7)$ & $4 / 7$ & $5 / 7$ & $0 / 7$ & $2 / 7$ & $5 / 7$ & $0 / 5$ & $2 / 3$ & $1 / 7$ & $5 / 7$ & $3 / 7$ & $1 / 7$ & $1 / 7$ & $0 / 7$ & $2 / 7$ & $1 / 7$ \\
\hline Steno bredanensis $(n=1)$ & $0 / 1$ & $1 / 1$ & $0 / 1$ & $1 / 1$ & $1 / 1$ & $0 / 1$ & N.A & $0 / 1$ & $1 / 1$ & $1 / 1$ & $0 / 1$ & $0 / 1$ & $0 / 1$ & $0 / 1$ & $0 / 1$ \\
\hline Tursiops aduncus $(n=1)$ & $1 / 1$ & $1 / 1$ & $0 / 1$ & $1 / 1$ & $1 / 1$ & $1 / 1$ & $1 / 1$ & $1 / 1$ & $1 / 1$ & $0 / 1$ & $0 / 1$ & $0 / 1$ & $0 / 1$ & $0 / 1$ & $1 / 1$ \\
\hline Tursiops truncatus $(n=9)$ & $7 / 9$ & $6 / 9$ & $0 / 9$ & $5 / 9$ & $5 / 9$ & $0 / 3$ & $3 / 3$ & $0 / 9$ & $7 / 9$ & $4 / 9$ & $1 / 9$ & $0 / 9$ & $0 / 9$ & $2 / 9$ & $0 / 9$ \\
\hline Ziphius cavirostris $(n=1)$ & $1 / 1$ & $1 / 1$ & $1 / 1$ & $1 / 1$ & $0 / 1$ & $0 / 1$ & $1 / 1$ & $0 / 1$ & $1 / 1$ & $1 / 1$ & 0/1 & $0 / 1$ & $0 / 1$ & $0 / 1$ & $0 / 1$ \\
\hline$\%$ of all cases & 79 & 81 & 18 & 59 & 64 & 19 & 82 & 7 & 82 & 49 & 3 & 10 & 4 & 11 & 11 \\
\hline
\end{tabular}

Number of individuals by species in the different descriptive terms.

$C D$, circulatory disease; RD, respiratory disease; UD, urinogenital disease; GD, gastrointestinal disease; HPD, hepatobiliary-pancreatic disease; CNSD, CNS disease; Bl, bacterial infection; VI, viral infection; Pal, parasite infestation; SPal, severe parasite infestation; SA, shark attack; PI, pregnant individual; MSC, maternal separated calf; GFBs, gastrointestinal foreign bodies; HR, human-related.

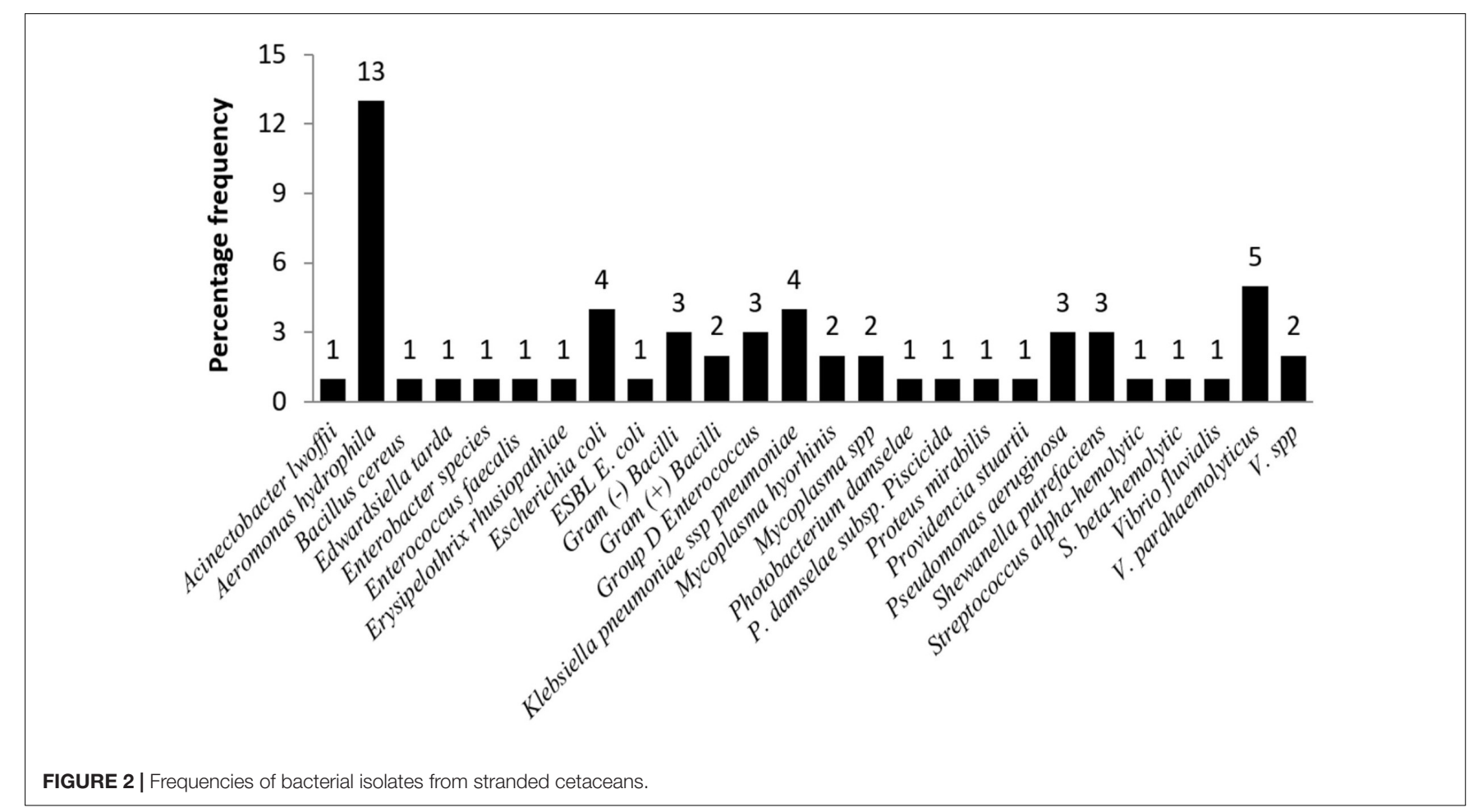

antibiotics, but one isolate $(1 / 38,3 \%)$ of $E$. coli was extendedspectrum $\beta$-lactamases (ESBL) E. coli. The ESBL E. coli was isolated from lung and kidney tissues of a stranded melon-headed whale (Peponocephala electra).
There were 59 individuals (81\%) with respiratory diseases, including parasitic bronchopneumonia, interstitial pneumonia, congestion, and edema, 58 (79\%) having circulatory diseases, and $54(74 \%)$ diagnosed as cardiomyopathy, and congestive 
hepatopathy (nutmeg liver) $(37 \%, 27 / 73)$ and multiple organ congestion $(49 \%, 36 / 73)$ secondary to cardiac failure were commonly found in these stranded cetaceans. Cardiomyopathy cases were further categorized into acute stress-induced cardiomyopathy $(S I C)$, dilated cardiomyopathy (DCM), and myocardial patchy fibrosis (MPF). Forty-one individuals of the 73 cases $(56 \%)$ had contraction band necrosis, wavy myofibers, myocardial degeneration/necrosis, and interstitial edema, which were features of SIC. Moreover, 26 individuals (36\%) had the features of DCM including globular heart, flabby ventricular walls, and local-extensive myocardial fibrosis, and 12 individuals (16\%) had MPF. Mixed-type (having microscopic components of both acute and DCM or MPF features) cardiomyopathy was noted in 25 individuals (34\%) of the cases, while 16 and 13 individuals were diagnosed as solely acute and DCM or MPF, respectively.

Hepatobiliary-pancreatic diseases were found in 47 individuals of cases (64\%), including elevated ALT, congestive hepatopathy (sinusoidal dilatation/congestion and hepatic lipidosis), and chronic portal hepatitis. Forty-three individuals (59\%) of the cases had gastrointestinal diseases, and 36 (50\%) had ulcerative gastritis (with or without parasite infestation). Of the 43 cases with collected CNS tissues and/or blood samples to evaluate CNS pathology and activity of Creatine Kinase-BB (CK$\mathrm{BB}), 19 \%$ (8/43) had pathological changes of CNS (meningitis and encephalitis), and/or elevated CK-BB. Moreover, urogenital disease such as nephritis, nephropathy, and cortical necrosis were noted in $18 \%(13 / 73)$ of the cases.

There were 60 individuals with varying degrees of parasite infestation (82\%), with 36 of the cases recorded as severe infestation (49\%). Among the 38 individuals that were examined for bacteriology, 31 of them (82\%) were found to have bacterial infections (14 had systemic infections, 12 had pneumonia, and 5 had hepatitis or pyelonephritis). Only four cases (5\%) with virus-related skin lesions were noted, and no direct evidences of viral infection (i.e., inclusion bodies) were observed microscopically. These four cases are white-fringed spots in the Indo-Pacific bottlenose dolphin (Tursiops aduncus) (herpesvirus suspected), black spots, and tattoos in the Fraser's dolphin (Lagenodelphis hosei) (poxvirus suspected), a pale yellow to white, smooth surface, and raised plaques of genital mucosa in the pantropical spotted dolphin (Stenella attenuata) (papillomavirus/herpesvirus suspected), and genital warts in the dwarf sperm whale (Kogia sima) (papillomavirus/herpesvirus suspected). However, the actual incidence of viral infection in the present study could not be determined since no molecular diagnosis was performed.

Eight (11\%) of the cases were categorized as direct humanrelated traumas, including seven cases with entanglement marks and one with propeller strike. Gastrointestinal foreign bodies (macroplastics and other foreign objects) were found in eight individuals (11\%); seven (10\%) had ulcerative gastritis; and five (7\%) had pathology associated with a significant loss of body condition. Seven female cetaceans (10\%) were pregnant. Three of the cases (4\%) were categorized as maternal separated calf. Two individuals (3\%) were categorized as shark attack. Cases are summarized by species in Table $\mathbf{1}$.

\section{DISCUSSION}

Parasite infestation is considered as a common finding in cetaceans worldwide, and the present study revealed a similar prevalence of parasite infestation $(82 \%, 60 / 73)$ when compared to other studies (Cornaglia et al., 2000; Parsons and Jefferson, 2000; Jauniaux et al., 2002; Lehnert et al., 2005; Siebert et al., 2006; Fauquier et al., 2009; Oliveira et al., 2011). However, it is surprising that the prevalence of severe parasite infestation of stranded cetaceans in Taiwan $(49 \%, 36 / 73)$ is higher than that in Hong Kong waters $(19 \%, 6 / 32)$ and in the German North Sea (39\%, 11/28) (Parsons and Jefferson, 2000; Lehnert et al., 2005). Previous studies in cetaceans and humans have indicated that compromised immune function may increase the susceptibility to parasites infestation (Siebert et al., 1999; Tourchin et al., 2002; Evering and Weiss, 2006). Therefore, our results imply that wild cetacean populations around Taiwanese waters may face a level of stress that could compromise their immune function (Chen et al., 2018; Marsili et al., 2019).

Environmental pollutants are also considered to be associated with compromised immune function (Jepson et al., 1999; Siebert et al., 1999; Romero and Butler, 2007; Li et al., 2018b,d). Previous studies have indicated that cetaceans in Taiwanese waters have relatively low levels of polychlorinated biphenyls (PCBs), mercury ( $\mathrm{Hg})$, and polybrominated dipheyl ethers (PBDEs) (Chen et al., 2002; Chou et al., 2004; Ko et al., 2014). However, recent studies have demonstrated that cetaceans in Taiwanese waters may suffer from negative health impacts caused by the contamination of heavy metals, including silver (Ag) and Cadmium (Cd) (Chen et al., 2017; Li et al., 2018a,c).

In this study, most of the bacteria isolated from stranded dolphins were zoonotic pathogens, which have been reported previously (Higgins, 2000; Waltzek et al., 2012). Most importantly, multidrug resistant (MDR) bacteria were also isolated from stranded cetaceans in Taiwan. MDR bacteria have caused many hard-to-treat infections and mortalities in humans, hence it has become a serious concern worldwide (Allahverdiyev et al., 2013). The presence of MDR bacteria in marine mammals also indicates MDR bacteria and genes may exist in the marine environment. Once in the marine environment, other bacteria may obtain MDR genes, resulting in a gradual increase in the amount of MDR bacteria (Kruse and Sorum, 1994). The results of the current study indicate MDR bacteria and/or pathogenic bacteria exist in marine environment and in cetaceans populations in Taiwanese waters, and this may be transmitted to humans, especially coastal residents, tourists, and cetacean rescue personnel (Schaefer et al., 2009; Waltzek et al., 2012). The sources of MDR bacteria and genes have been directly linked to widespread use of antimicrobial drugs in humans and livestock (Schaefer et al., 2009). The antimicrobial drugs and MDR bacteria may exist in agricultural and domestic wastewater, even in treated wastewater (LaPara et al., 2011), and would ultimately drain into the coastal waters and ocean as runoff (Schaefer et al., 2009). It has been suggested that higher exposure of freshwater runoff was a significant risk factor for northern elephant seals in California to acquire MDR and 
pathogenic bacteria, which were transmitted via surface waters (Stoddard et al., 2008).

An investigation conducted by Taiwan Environmental Protection Administration (TEPA) indicated that approximately $26.5 \%$ ( $\mathrm{SD}=2.16)$ of major rivers were moderately or severely polluted by domestic, industrial, and agricultural wastewaters in Taiwan between 2001 and 2019, despite the percentage of severely polluted major rivers gradually decreasing from 15.8 to 2.8\%. ${ }^{2}$ Moreover, according to the records from the Construction and Planning Agency of Minister of the Interior (CPAMI), integrate sewage treatment rate of Taiwan was $62.1 \%$ in $2019 .{ }^{3}$ In other words, about $38 \%$ of all wastewater was directly drained, untreated, into the ocean around Taiwan. In addition, natural wetlands have been gradually destroyed by urbanization in Taiwan (Lin, 2010). Wetlands are natural purification system and could help reduce the level of pollution from contaminated surface water runoff to the ocean (Kao and $\mathrm{Wu}, 2001$ ). Therefore, we presume that untreated wastewater serves as an important route to transmit MDR bacteria and genes from terrestrial origins to marine ecosystem in Taiwan.

Although only $11 \%(8 / 73)$ of cases were attributed to direct human-related causes in this study, the negative impacts of anthropogenic stressors may be underestimated. Only cetaceans with apparent evidence of vessel strike and entanglement - as the direct cause of death/stranding - were categorized as direct human-related cases. Previous studies have identified several potential human-related stressors in cetaceans in Taiwanese waters (Yu, 2000; Kuo, 2002; Williams et al., 2006; Lachmuth et al., 2011; Lin, 2012; Steckenreuter et al., 2012). For example, human-related scars, such as cuts (lacerations) and impression marks, were found in $42 \%$ (30/71) of Chinese white dolphins inhabit in the coastal waters of western Taiwan, and were suggested to be associated with heavy fishing activity and vessel traffic (Lin, 2012). A previous study on the impact of fishery bycatch on cetaceans in Taiwan revealed that the bycatch rate was $0.18-0.4$ dolphins/boat/day in southeast Taiwan, and the number of bycaught dolphins was estimated to be 3000 individuals/year (L.S. Chou, unpublished information). These studies demonstrate that cetaceans in Taiwanese waters have been severely impacted by fisheries and vessel traffic. These impacts may not kill cetaceans directly, but they could cause long-term sublethal effects (such as chronic stress and predation disturbance) in cetaceans in Taiwanese waters.

Previous studies have identified that cetaceans may show negative responses (increasing their breath intervals and decreasing their surfacing intervals) to whale-watching boat, and it may lead to decreased foraging, resting, and socializing time and increased traveling time (Williams et al., 2006; Lachmuth et al., 2011; Steckenreuter et al., 2012). Similar phenomenon has been reported in the whale-watching studies in the eastern Taiwanese waters and whale watching activities were suggested to be a potential stressor (Yu, 2000; Kuo, 2002). Daily whalewatching activities of the coast of Taiwan might potentially represent a long-term source of harassment for cetaceans, and

${ }^{2}$ https://data.epa.gov.tw/

${ }^{3}$ https://sewergis.cpami.gov.tw/sewersso/ may cause chronic stress. In addition, anthropogenic noise has been proven to cause negative impacts in cetaceans, such as behavioral disturbance (e.g., decreased feeding and resting time), acoustic disturbance (e.g., permanent or temporary threshold shifts and acoustic masking), habitat abandonment, and stressrelated physiological pathology (Nowacek et al., 2007; Weilgart, 2007; Wright et al., 2007; Yang et al., 2008; Chen et al., 2018). Furthermore, vessel noise can cause chronic stress and modulate immune function in cetaceans (Rolland et al., 2012). Due to heavy vessel traffic around Taiwanese waters, it is reasonable to presume that cetaceans in this region may have suffered from negative impacts of noise. Cumulatively, the health of cetacean populations in Taiwanese waters may have been affected by several human-related factors such as heavy fishery bycatch, vessel traffic, whale-watching activities, and vessel noise, and it is suggested that these human-related factors are important stressors in cetacean populations.

Cardiomyopathy was detected in a large proportion of cetaceans stranded on the coast of Taiwan (74\%). SIC is caused by massive endogenous catecholamine release due to acute event, such as stranding itself or human rescue interaction (Turnbull and Cowan, 1998; Bossart et al., 2007; Herraez et al., 2013; Câmara et al., 2020). The major lesions of SIC are contraction band necrosis, interstitial edema, wavy myofibers, spasm of intramural coronary arteries, and myocardial ischemia (Turnbull and Cowan, 1998; Bossart et al., 2007; Cowan and Curry, 2008; Herraez et al., 2013; Câmara et al., 2019). If the animal survives the acute, high stress event, myocardial necrosis, and ischemia may then form irregular patchy fibrosis, namely MPF (Cowan and Curry, 2008). The presence of fibrosis indicates an earlier cardiomyocyte damage has occurred before the latest stranding (Câmara et al., 2020). In contrast to SIC, DCM is associated with chronic stress (long-term excessive cortisol release or repeat stressful events) and nutrition deficiency (e.g., L-carnitine and taurine) (Bossart et al., 2007; Cowan and Curry, 2008; Shibusawa et al., 2013). The gross features of DCM include globular appearance of the heart, thin and flabby ventricular walls, and increased ventricular volume (Bossart et al., 2007; Maxie and Robinson, 2007). Microscopically, DCM is characterized by anisokaryosis and anisocytosis of cardiomyocytes, cardiomyocytes degeneration/necrosis, and local-extensive myocardial fibrosis (Bossart et al., 2007; Maxie and Robinson, 2007). The mixed-type cardiomyopathy found in the current study has been suggested to be a common finding in stranded cetaceans (Bossart et al., 2007; Cowan and Curry, 2008). Overall, 52\% (38/73) of the individuals have MPF and DCM in this study although the causation of the high prevalence is not confirmed. Further study on the relationship between cardiomyopathy and the multiple stressors mentioned above is warranted for evaluating the impacts of repeatedly stressful event exposure and chronic stress in the cetaceans in Taiwanese waters.

In total, seven pregnant individuals were identified in this study (Table 1). A previous study conducted in common bottlenose dolphins have demonstrated that their morphology, hydrodynamics, and kinematics were altered during pregnancy, including decreased locomotor performance and thereby increased risk of predation (Noren et al., 2011). In addition, 
pregnancy in humans has been demonstrated to modulate the immune function and may increase the susceptibility to infection (Racicot et al., 2014). Although the effects caused by pregnancy on immune function in cetaceans is still unclear, pregnant cetaceans with decreased locomotor performance could be at greater risk of stranding. Calves separated from their mothers prior to weaning may likely suffer from malnourishment but also may not be able to learn critical social, foraging, and predator-avoidance strategies (Hayssen, 1993; Bogomolni et al., 2010). Notably, a maternally separated Fraser's dolphin in this study had anthropogenic trauma on the peduncle, indicating the lack of efficient maternal protection.

Shark bite wounds possibly caused by requiem sharks on a T. truncatus caused severe cellulitis and myositis with subsequent septicemia. In addition, multiple shark bite wounds caused by cookie cutter sharks were noted on the abdomen of a S. attenuata. Bite wounds caused by cookie cutter shark have been reported in 50 species of cetaceans (Dwyer and Visser, 2011; Luksenburg, 2014), and they are not considered lethal in most instances. Nevertheless, the bite wounds in this S. attenuata were deep enough to involve the subjacent muscle layer, which may have increased the risk of secondary septicemia as the cause of death.

Gastrointestinal foreign bodies were found in eight individuals. Plastic packaging (bags and wrappings) were recovered from seven individuals and fishing line from a single specimen. Although gastrointestinal foreign bodies in our investigation were small fragments, the negative effects caused should not be overlooked. Macroplastics may be retained in the stomach for a long period of time, and have the potential to decrease the feeding stimulus as well as providing a source of toxic pollutants (Ryan, 1987; Rios et al., 2007; Rochman et al., 2013; Puig-Lozano et al., 2018; Huang et al., 2021). Thereafter, the energy acquisition and health of affected cetaceans may be compromised, including decreased resistance to predators and diseases as well as reduced reproductive success (Laist, 1987; Ryan, 1987; Rios et al., 2007; Denuncio et al., 2011; Currie et al., 2017).

\section{Ongoing and Future Research}

The present study demonstrated that cetaceans around Taiwanese waters are exposed to stress, and hence we suggest stress and related anthropogenic factors in cetaceans should be monitored and managed. Cardiomyopathy is an indicator of stress and nutritional deficiency (Bossart et al., 2007; Câmara et al., 2020), and thus periodic investigation of cardiomyopathy in stranded cetaceans is recommended for monitoring the level of stress in wild cetacean populations. Anthropogenic stress factors, including fishery bycatch, vessel traffic, whale-watching activities, and vessel noise, should be further monitored and managed. Studying the stomach contents in stranded cetaceans enables us to understand their habitat, prey preference, nutritional intake (Dunshea et al., 2013), and marine debris ingestion (PuigLozano et al., 2018), and also indirectly evaluate the impacts of bycatch and high-intensity anthropogenic noise. The severity of parasite infestation reflects the level of immunosuppression in cetaceans, and hence monitoring the severity of parasitic infections in stranded cetaceans is recommended. In addition, immunosuppressive factors such as levels of environmental contaminants and prevalence of morbillivirus infections should be evaluated. Previous studies of contaminant levels of PCBs and $\mathrm{Hg}$ in cetaceans in Taiwan were conducted almost two decades ago (Chen et al., 2002; Chou et al., 2004), and therefore need to be reassessed. Furthermore, morbillivirus infections not only causes mass mortality events in cetaceans, but also compromises immune function (Raga et al., 2008). Morbillivirus infection was reported in a pygmy sperm whale (Kogia breviceps) stranded in Taiwan in 1999 and it was suggested that morbillivirus is present in Taiwanese waters (Yang et al., 2006). On the basis of this evidence, an investigation of morbillivirus infection in stranded cetaceans around Taiwanese waters and its adjacent areas should be conducted (Yang et al., 2016). Monitoring of other viral infections would be also important because the epidemiological patterns of the viral infections are likely associated with stress and immunosuppression, and may be an indicator of cetacean population health (Van Bressem et al., 2009; Soto et al., 2012).

In addition to the stressor monitoring mentioned above, using cetaceans as marine sentinels permits better characterization and management of impacts that ultimately affect cetacean and human health associated with the oceans. As ocean health is tightly connected to human health, an indicator which provides information on ocean health is essential for our well-being (Knap et al., 2002). The concept that environmental health could be evaluated via understanding the health status of sentinel species is well documented in the literature (Reif, 2011). Marine mammals such as cetaceans are used as sentinels worldwide for multiple reasons (Bossart, 2011). Cetaceans occupy high trophic levels of a marine ecosystem and share food resources with humans, and therefore, provide an indication of contaminant bioaccumulation in humans (Bossart, 2011). Likewise, many diseases which affect cetaceans may be also harmful for humans, such as zoonotic diseases and algal blooms (Van Bressem et al., 2009; Waltzek et al., 2012). For instance, zoonotic pathogen T. gondii has been investigated in marine mammals to evaluate ocean contamination with T. gondii oocysts (Alvarado-Esquivel et al., 2012). The presence of antibiotic resistant bacteria in the marine environment, an emerging public health issue, has also been investigated through examinations of wild Atlantic bottlenose dolphins (T. truncatus) (Schaefer et al., 2009). Furthermore, $\mathrm{Hg}$ and $\mathrm{Ag}$ contamination in the marine environment can be evaluated by surveying their concentrations in the tissues of wild cetaceans (Savery et al., 2013; Chen et al., 2017; Li et al., 2018a,c). Multidrug resistant bacteria in stranded cetaceans not only indicate that the marine environment around Taiwan has been contaminated, but also provides an early warning of potential MDR bacterial infection for humans. Thus, we also suggest that MDR bacteria of stranded cetaceans in Taiwan should be monitored. Moreover, in order to reduce MDR bacterial contamination levels in the marine environment around Taiwan, we suggest that the improvement of sewage treatment facilities and wetland conservation and restoration should be prioritized.

In conclusion, the evidence present in this study indicates that the cetaceans around Taiwanese waters may suffer from immunosuppression as a result of multiple anthropogenic stressors, including fishery bycatch, vessel traffic, whale-watching 
activities, vessel noise, and land-based pollution. Pathogenic and MDR bacteria were also cultured from stranded cetaceans, and should be considered as an early warning of potential zoonotic risks. Finally, the results of this study also provide valuable recommendations for cetacean conservation and potential zoonotic risks in Taiwan. In addition, we are appealing to other countries in the western Pacific region to collect consistent samples and data from stranded cetaceans. Further studies focused on disease investigation of stranded cetaceans could allow us to further understand the critical threats to cetaceans, ocean, and human health.

\section{DATA AVAILABILITY STATEMENT}

The raw data supporting the conclusion of this article will be made available by the authors, without undue reservation.

\section{ETHICS STATEMENT}

The animal study was reviewed and approved by Council of Agriculture, Taiwan.

\section{REFERENCES}

Allahverdiyev, A. M., Bagirova, M., Abamor, E. S., Ates, S. C., Koc, R. C., Miraloglu, M., et al. (2013). The use of platensimycin and platencin to fight antibiotic resistance. Infect Drug Resist. 6, 99-114. doi: 10.2147/idr.s25076

Alvarado-Esquivel, C., Sanchez-Okrucky, R., and Dubey, J. P. (2012). Serological evidence of Toxoplasma gondii infection in captive marine mammals in Mexico. Vet. Parasitol. 184, 321-324. doi: 10.1016/j.vetpar.2011.08.036

Arbelo, M., Los Monteros, A. E., Herraez, P., Andrada, M., Sierra, E., Rodriguez, F., et al. (2013). Pathology and causes of death of stranded cetaceans in the Canary Islands (1999-2005). Dis. Aquat. Organ. 103, 87-99. doi: 10.3354/dao02558

Bogomolni, A. L., Pugliares, K. R., Sharp, S. M., Patchett, K., Harry, C. T., Larocque, J. M., et al. (2010). Mortality trends of stranded marine mammals on Cape Cod and southeastern Massachusetts, USA, 2000 to 2006. Dis. Aquat. Organ. 88, 143-155. doi: 10.3354/dao02146

Bonar, C. J., Boede, E. O., Hartmann, M. G., Lowenstein-Whaley, J., MujicaJorquera, E., Parish, S. V., et al. (2007). A retrospective study of pathologic findings in the Amazon and Orinoco river dolphin (Inia geoffrensis) in captivity. J. Zoo. Wildl. Med. 38, 177-191. doi: 10.1638/1042-7260(2007) 038[0177:arsopf $] 2.0 . \mathrm{co} ; 2$

Bossart, G. D. (2011). Marine mammals as sentinel species for oceans and human health. Vet. Pathol. 48, 676-690. doi: 10.1177/0300985810388525

Bossart, G. D., Hensley, G., Goldstein, J. D., Kroell, K., Manire, C. A., Defran, R. H., et al. (2007). Cardiomyopathy and myocardial degeneration in stranded pygmy (Kogia breviceps) and dwarf (Kogia sima) sperm whales. Aquat. Mammals 33, 214-222. doi: 10.1578/am.33.2.2007.214

Bossart, G. D., Reidarson, T. H., Dierauf, L. A., and Duffield, D. A. (2001). "Clinical Pathology," in CRC Handbook of Marine Mammal Medicine, 2 Edn, eds L. A. Dierauf, and F. M. D. Gulland (Boca Raton, FL: CRC Press), 383-436.

Câmara, N., Sierra, E., Fernandez, A., Arbelo, M., Andrada, M., Monteros, A. E. L., et al. (2020). Increased plasma cardiac Troponin I in live-stranded cetaceans: correlation with pathological findings of acute cardiac injury. Sci. Rep. 10:1555.

Câmara, N., Sierra, E., Fernández-Maldonado, C., Espinosa de Los Monteros, A., Arbelo, M., Fernández, A., et al. (2019). Stress cardiomyopathy in stranded cetaceans: a histological, histochemical and immunohistochemical study. Vet. Rec. 185:694. doi: 10.1136/vr.105562

\section{AUTHOR CONTRIBUTIONS}

W-TL: experiment performance, analysis or interpretation of data, and manuscript writing. L-SC: conception. H-YC: conception and design and sample collection. I-HC: experiment performance and sample collection. W-CY: analysis or interpretation of data, critical revision, and final approval of the manuscript. All authors read, corrected, and approved the final version of this manuscript.

\section{FUNDING}

This study was partially funded by the Forest Bureau, Council of Agriculture, Taiwan.

\section{ACKNOWLEDGMENTS}

We thank Council of Agriculture Taiwan for long-term economically supporting the stranding network and research. We also thank the scholars and staff in National Taiwan University and Taiwan Cetacean Society for responding stranding events and collecting valuable samples.

Chen, I. H., Chou, L.-S., Chou, S.-J., Wang, J.-H., Stott, J., Blanchard, M., et al. (2018). Sound exposure-induced cytokine gene transcript profile changes in captive bottlenose dolphin (Tursiops truncatus) blood identified by a probe-based qRT-PCR. J. Vet. Med. Sci. 80, 601-605. doi: 10.1292/jvms.170548

Chen, M. H., Shih, C. C., Chou, C. L., and Chou, L. S. (2002). Mercury, organicmercury and selenium in small cetaceans in Taiwanese waters. Mar. Pollut. Bull. 45, 237-245. doi: 10.1016/s0025-326x(02)00095-4

Chen, M. H., Zhuang, M. F., Chou, L. S., Liu, J. Y., Shih, C. C., and Chen, C. Y. (2017). Tissue concentrations of four Taiwanese toothed cetaceans indicating the silver and cadmium pollution in the western Pacific Ocean. Mar. Pollut. Bull. 124, 993-1000. doi: 10.1016/j.marpolbul.2017.03.028

Chou, C. C., Chen, Y. N., and Li, C. S. (2004). Congener-specific polychlorinated biphenyls in cetaceans from Taiwan waters. Arch. Environ. Contam. Toxicol. 47, 551-560. doi: 10.1007/s00244-004-3214-y

Cornaglia, E., Rebora, L., Gili, C., and Di Guardo, G. (2000). Histopathological and immunohistochemical studies on cetaceans found stranded on the coast of Italy between 1990 and 1997. J. Vet. Med. A Physiol. Pathol. Clin. Med. 47, 129-142. doi: 10.1046/j.1439-0442.2000.00268.x

Cowan, D. F., and Curry, B. E. (2008). Histopathology of the alarm reaction in small odontocetes. J. Comp. Pathol. 139, 24-33. doi: 10.1016/j.jcpa.2007.11.009

Currie, J. J., Stack, S. H., Mccordic, J. A., and Kaufman, G. D. (2017). Quantifying the risk that marine debris poses to cetaceans in coastal waters of the 4-island region of Maui. Mar. Pollut. Bull. 121, 69-77. doi: 10.1016/j.marpolbul.2017. 05.031

Denuncio, P., Bastida, R., Dassis, M., Giardino, G., Gerpe, M., and Rodriguez, D. (2011). Plastic ingestion in Franciscana dolphins, Pontoporia blainvillei (Gervais and d'Orbigny, 1844), from Argentina. Mar. Pollut. Bull. 62, 18361841. doi: 10.1016/j.marpolbul.2011.05.003

Di Guardo, G., Di Francesco, C. E., Eleni, C., Cocumelli, C., Scholl, F., Casalone, C., et al. (2013). Morbillivirus infection in cetaceans stranded along the Italian coastline: pathological, immunohistochemical and biomolecular findings. Res. Vet. Sci. 94, 132-137. doi: 10.1016/j.rvsc.2012.07.030

Diaz-Delgado, J., Fernandez, A., Sierra, E., Sacchini, S., Andrada, M., Vela, A. I., et al. (2018). Pathologic findings and causes of death of stranded cetaceans in the Canary Islands (2006-2012). PLoS One 13:e0204444. doi: 10.1371/journal. pone.0204444 
Dunshea, G., Barros, N. B., Berens Mccabe, E. J., Gales, N. J., Hindell, M. A., Jarman, S. N., et al. (2013). Stranded dolphin stomach contents represent the free-ranging population's diet. Biol. Lett. 9:20121036. doi: 10.1098/rsbl.2012. 1036

Dwyer, S. L., and Visser, I. N. (2011). Cookie Cutter Shark (Isistius sp.) bites on cetaceans, with particular reference to killer whales (Orca) (Orcinus orca). Aquat. Mammals 37, 111-138. doi: 10.1578/am.37.2.2011.111

Evering, T., and Weiss, L. M. (2006). The immunology of parasite infections in immunocompromised hosts. Parasite Immunol. 28, 549-565.

Fauquier, D. A., Kinsel, M. J., Dailey, M. D., Sutton, G. E., Stolen, M. K., Wells, R. S., et al. (2009). Prevalence and pathology of lungworm infection in bottlenose dolphins Tursiops truncatus from southwest Florida. Dis. Aquat. Organ. 88, 85-90. doi: 10.3354/dao02095

Forman, D., West, N., Francis, J., and Guy, E. (2009). The sero-prevalence of Toxoplasma gondii in British marine mammals. Mem. Inst. Oswaldo Cruz. 104, 296-298. doi: 10.1590/s0074-02762009000200024

Geraci, J. R., and Lounsbury, V. J. (2005). Marine Mammals Ashore: A Field Guide for Strandings: Specimen and Data Colletion. Baltimore, MD: National Aquarium in Baltimore, 167-230.

Hart, L. B., Rotstein, D. S., Wells, R. S., Allen, J., Barleycorn, A., Balmer, B. C., et al. (2012). Skin lesions on common bottlenose dolphins (Tursiops truncatus) from three sites in the Northwest Atlantic, USA. PLoS One 7:e33081. doi: 10.1371/journal.pone.0033081

Hayssen, V. (1993). Empirical and theoretical constraints on the evolution of lactation. J. Dairy Sci. 76, 3213-3233. doi: 10.3168/jds.s00220302(93)77659-6

Herraez, P., Espinosa De Los Monteros, A., Fernandez, A., Edwards, J. F., Sacchini, S., and Sierra, E. (2013). Capture myopathy in live-stranded cetaceans. Vet. J. 196, 181-188. doi: 10.1016/j.tvjl.2012.09.021

Higgins, R. (2000). Bacteria and fungi of marine mammals: a review. Can. Vet. J. $41,105-116$

Huang, W., Song, B., Liang, J., Niu, Q., Zeng, G., Shen, M., et al. (2021). Microplastics and associated contaminants in the aquatic environment: a review on their ecotoxicological effects, trophic transfer, and potential impacts to human health. J. Hazard. Mater. 405:124187. doi: 10.1016/j.jhazmat.2020. 124187

Hunt, K. E., Moore, M. J., Rolland, R. M., Kellar, N. M., Hall, A. J., Kershaw, J., et al. (2013). Overcoming the challenges of studying conservation physiology in large whales: a review of available methods. Conserv. Physiol. 1:cot006. doi: 10.1093/conphys/cot006

IJsseldijk, L. L., Brownlow, A. C., and Mazzariol, S. (2019). European Best Practice on Cetacean Post-Mortem Investigation and Tissue Sampling. Joint ACCOBAMS and ASCOBANS Document Charlottesville, VA: OSF Preprints. doi: 10.31219/ osf.io/zh4ra

Inskeep, W. II, Gardiner, C. H., Harris, R. K., Dubey, J. P., and Goldston, R. T. (1990). Toxoplasmosis in Atlantic bottle-nosed dolphins (Tursiops truncatus). J. Wildl. Dis. 26, 377-382. doi: 10.7589/0090-3558-26.3.377

Jauniaux, T., Petitjean, D., Brenez, C., Borrens, M., Brosens, L., Haelters, J., et al. (2002). Post-mortem findings and causes of death of harbour porpoises (Phocoena phocoena) stranded from 1990 to 2000 along the coastlines of Belgium and Northern France. J. Comp. Pathol. 126, 243-253. doi: 10.1053/ jcpa.2001.0547

Jepson, P. D., Bennett, P. M., Allchin, C. R., Law, R. J., Kuiken, T., Baker, J. R., et al. (1999). Investigating potential associations between chronic exposure to polychlorinated biphenyls and infectious disease mortality in harbour porpoises from England and Wales. Sci. Total Environ. 243-244, 339-348. doi: 10.1016/ s0048-9697(99)00417-9

Kao, C. M., and Wu, M. J. (2001). Control of non-point source pollution by a natural wetland. Water Sci. Technol. 43, 169-174. doi: 10.2166/wst.2001.0278

Knap, A., Dewailly, E., Furgal, C., Galvin, J., Baden, D., Bowen, R. E., et al. (2002). Indicators of ocean health and human health: developing a research and monitoring framework. Environ. Health Perspect. 110, 839-845. doi: 10.1289/ ehp.02110839

Ko, F. C., We, N. Y., and Chou, L. S. (2014). Bioaccumulation of persistent organic pollutants in stranded cetaceans from Taiwan coastal waters. J. Hazard. Mater. 277, 127-133. doi: 10.1016/j.jhazmat.2013.12.057

Kruse, H., and Sorum, H. (1994). Transfer of multiple drug resistance plasmids between bacteria of diverse origins in natural microenvironments.
Appl. Environ. Microbiol. 60, 4015-4021. doi: 10.1128/aem.60.11.4015-4021. 1994

Kuo, C. Y. (2002). Effect of Whale-Watching Boats on Behavior of Risso's Dolphins (Grampus griseus) in the Coastal Waters of Southeastern Taiwan. Master Unpublished Master thesis. Taipei: National Taiwan University.

Lachmuth, C. L., Barrett-Lennard, L. G., Steyn, D. Q., and Milsom, W. K. (2011). Estimation of southern resident killer whale exposure to exhaust emissions from whale-watching vessels and potential adverse health effects and toxicity thresholds. Mar. Pollut. Bull. 62, 792-805. doi: 10.1016/j.marpolbul.2011. 01.002

Laist, D. W. (1987). Overview of the biological effects of lost and discarded plastic debris in the marine-environment. Mar. Pollut. Bull. 18, 319-326. doi: 10.1016/ s0025-326x(87)80019-x

LaPara, T. M., Burch, T. R., Mcnamara, P. J., Tan, D. T., Yan, M., and Eichmiller, J. J. (2011). Tertiary-treated municipal wastewater is a significant point source of antibiotic resistance genes into Duluth-Superior Harbor. Environ. Sci. Technol. 45, 9543-9549. doi: 10.1021/es202775r

Lehnert, K., Raga, J. A., and Siebert, U. (2005). Macroparasites in stranded and bycaught harbour porpoises from German and Norwegian waters. Dis. Aquat. Organ. 64, 265-269. doi: 10.3354/dao064265

Li, W. T., Chang, H. W., Chen, M. H., Chiou, H. Y., Liou, B. Y., Pang, V. F., et al. (2018a). Investigation of silver (Ag) deposition in tissues from stranded cetaceans by autometallography (AMG). Environ. Pollut. 235, 534-545. doi: 10.1016/j.envpol.2018.01.010

Li, W. T., Chang, H. W., Yang, W. C., Lo, C., Wang, L. Y., Pang, V. F., et al. (2018b). Immunotoxicity of Silver Nanoparticles (AgNPs) on the leukocytes of common bottlenose dolphins (Tursiops truncatus). Sci. Rep. 8:5593.

Li, W. T., Liou, B. Y., Yang, W. C., Chen, M. H., Chang, H. W., Chiou, H. Y., et al. (2018c). Use of autometallography to localize and semi-quantify silver in cetacean tissues. J. Vis. Exp. 140:58232.

Li, W. T., Wang, L. Y., Chang, H. W., Yang, W. C., Lo, C., Pang, V. F., et al. (2018d). Th2 cytokine bias induced by silver nanoparticles in peripheral blood mononuclear cells of common bottlenose dolphins (Tursiops truncatus). PeerJ 6:e5432. doi: $10.7717 /$ peerj. 5432

Lin, M. C. (2012). Studies on the Scars of Humpback Dolphins, Sousa chinensis, in Taiwan. Master Unpublished Master thesis. Taipei: National Taiwan University.

Lin, Y. S. (2010). The Study of Wetlands Policy Based on the Ecosystem Management Concept. Master thesis. New Taipei: National Taipei University.

Luksenburg, J. A. (2014). Prevalence of external injuries in small cetaceans in Aruban waters, southern Caribbean. PLoS One 9:e88988. doi: 10.1371/journal. pone.0088988.g004

Marsili, L., Di Guardo, G., Mazzariol, S., and Casini, S. (2019). Insights Into cetacean immunology: do ecological and biological factors make the difference? Front. Immunol. 10:1219. doi: 10.3389/fimmu.2019.01219

Maxie, M. G., and Robinson, W. F. (2007). "Cardiovascular system," in Jubb, Kennedy and Palmer's Pathology of Domestic Animals, 5 Edn, ed. M. G. Mexie (Philadelphia, PA: Elsevier Saunders), 1-105.

McFee, W. E., and Lipscomb, T. P. (2009). Major pathologic findings and probable causes of mortality in bottlenose dolphins stranded in South Carolina from 1993 to 2006. J. Wildl. Dis. 45, 575-593. doi: 10.7589/0090-3558-45. 3.575

Miller, D. L., Woshner, V., Styer, E. L., Ferguson, S., Knott, K. K., Gray, M. J., et al. (2011). Histologic findings in free-ranging Sarasota Bay bottlenose dolphin (Tursiops truncatus) skin: mercury, selenium, and seasonal factors. J. Wildl. Dis. 47, 1012-1018. doi: 10.7589/0090-3558-47.4.1012

Moore, M. J., Der Hoop, J., Barco, S. G., Costidis, A. M., Gulland, F. M., Jepson, P. D., et al. (2013). Criteria and case definitions for serious injury and death of pinnipeds and cetaceans caused by anthropogenic trauma. Dis. Aquat. Organ. 103, 229-264. doi: 10.3354/dao02566

Noren, S. R., Redfern, J. V., and Edwards, E. F. (2011). Pregnancy is a drag: hydrodynamics, kinematics and performance in pre- and postparturition bottlenose dolphins (Tursiops truncatus). J. Exp. Biol. 214, 4151-4159. doi: 10.1242/jeb.059121

Nowacek, D. P., Thorne, L. H., Johnston, D. W., and Tyack, P. L. (2007). Responses of cetaceans to anthropogenic noise. Mammal Rev. 37, 81-115. doi: 10.1111/j. 1365-2907.2007.00104.x

Oliveira, J. B., Morales, J. A., Gonzalez-Barrientos, R. C., Hernandez-Gamboa, J., and Hernandez-Mora, G. (2011). Parasites of cetaceans stranded on the Pacific 
coast of Costa Rica. Vet. Parasitol. 182, 319-328. doi: 10.1016/j.vetpar.2011. 05.014

Parsons, E. C., and Jefferson, T. A. (2000). Post-mortem investigations on stranded dolphins and porpoises from Hong Kong waters. J. Wildl. Dis. 36, 342-356. doi: 10.7589/0090-3558-36.2.342

Puig-Lozano, R., Bernaldo, De Quirós, Y., Díaz-Delgado, J., García-Ñlvarez, N., Sierra, E., et al. (2018). Retrospective study of foreign body-associated pathology in stranded cetaceans, Canary Islands (2000-2015). Environ. Pollut. 243, 519527. doi: 10.1016/j.envpol.2018.09.012

Racicot, K., Kwon, J. Y., Aldo, P., Silasi, M., and Mor, G. (2014). Understanding the complexity of the immune system during pregnancy. Am. J. Reprod. Immunol. 72, 107-116. doi: 10.1111/aji.12289

Raga, J. A., Banyard, A., Domingo, M., Corteyn, M., Van Bressem, M. F., Fernandez, M., et al. (2008). Dolphin morbillivirus epizootic resurgence, Mediterranean Sea. Emerg. Infect. Dis. 14, 471-473. doi: 10.3201/eid1403.071230

Reddy, M. L., Dierauf, L. A., and Gulland, F. M. D. (2001). "Marine mammals as sentinels of ocean health," in CRC Handbook of Marine Mammal Medicine, 2 Edn, eds L. A. Dierauf, and F. M. D. Gulland (Boca Raton, FL: CRC Press).

Reif, J. S. (2011). Animal sentinels for environmental and public health. Public Health Rep. 126(Suppl. 1), 50-57. doi: 10.1177/00333549111260s108

Rios, L. M., Moore, C., and Jones, P. R. (2007). Persistent organic pollutants carried by synthetic polymers in the ocean environment. Mar. Pollut. Bull. 54, 1230-1237. doi: 10.1016/j.marpolbul.2007.03.022

Rochman, C. M., Browne, M. A., Halpern, B. S., Hentschel, B. T., Hoh, E., Karapanagioti, H. K., et al. (2013). Classify plastic waste as hazardous. Nature 494, 169-171.

Rolland, R. M., Parks, S. E., Hunt, K. E., Castellote, M., Corkeron, P. J., Nowacek, D. P., et al. (2012). Evidence that ship noise increases stress in right whales. Proc. Biol. Sci. 279, 2363-2368. doi: 10.1098/rspb.2011.2429

Romero, L. M., and Butler, L. K. (2007). Endocrinology of stress. Int. J. Comp. Psychol. 20, 89-95.

Ross, H. M., Foster, G., Reid, R. J., Jahans, K. L., and Macmillan, A. P. (1994). Brucella species infection in sea-mammals. Vet. Rec. 134:359. doi: 10.1136/vr. 134.14.359-b

Ryan, P. G. (1987). The incidence and characteristics of plastic particles ingested by seabirds. Mar. Environ. Res. 23, 175-206. doi: 10.1016/0141-1136(87)90028-6

Savery, L. C., Evers, D. C., Wise, S. S., Falank, C., Wise, J., Gianios, C. Jr., et al. (2013). Global mercury and selenium concentrations in skin from free-ranging sperm whales (Physeter macrocephalus). Sci. Total Environ. 45, 59-71. doi: 10.1016/j.scitotenv.2013.01.070

Schaefer, A. M., Goldstein, J. D., Reif, J. S., Fair, P. A., and Bossart, G. D. (2009). Antibiotic-resistant organisms cultured from Atlantic bottlenose dolphins (Tursiops truncatus) inhabiting estuarine waters of Charleston, SC and Indian River Lagoon, FL. Ecohealth 6, 33-41. doi: 10.1007/s10393-0090221-5

Schwacke, L. H., Smith, C. R., Townsend, F. I., Wells, R. S., Hart, L. B., Balmer, B. C., et al. (2014). Health of common bottlenose dolphins (Tursiops truncatus) in Barataria Bay, Louisiana, following the deepwater horizon oil spill. Environ. Sci. Technol. 48, 93-103.

Shibusawa, N., Yamada, M., Hashida, T., Hashimoto, K., Satoh, T., Horiguchi, J., et al. (2013). Dilated cardiomyopathy as a presenting feature of Cushing's syndrome. Intern. Med. 52, 1067-1071.

Siebert, U., Joiris, C., Holsbeek, L., Benke, H., Failing, K., Frese, K., et al. (1999). Potential relation between mercury concentrations and necropsy findings in cetaceans from German waters of the North and Baltic Seas. Mar. Pollut. Bull. 38, 285-295. doi: 10.1016/s0025-326x(98)00147-7

Siebert, U., Tolley, K., Vikingsson, G. A., Olafsdottir, D., Lehnert, K., Weiss, R., et al. (2006). Pathological findings in harbour porpoises (Phocoena phocoena) from Norwegian and Icelandic waters. J. Comp. Pathol. 134, 134-142. doi: 10.1016/j.jcpa.2005.09.002

Sierra, E., Sanchez, S., Saliki, J. T., Blas-Machado, U., Arbelo, M., Zucca, D., et al. (2014). Etiologic agents associated with non-suppurative meningoencephalitis in stranded cetaceans: a retrospective study in the Canary Islands. J. Clin. Microbiol. 52, 2390-2397.

Soto, S., Gonzalez, B., Willoughby, K., Maley, M., Olvera, A., Kennedy, S., et al. (2012). Systemic herpesvirus and morbillivirus co-infection in a striped dolphin (Stenella coeruleoalba). J. Comp. Pathol. 146, 269-273. doi: 10.1016/j.jcpa.2011. 04.002
Steckenreuter, A., Moller, L., and Harcourt, R. (2012). How does Australia's largest dolphin-watching industry affect the behaviour of a small and resident population of Indo-Pacific bottlenose dolphins? J. Environ. Manage. 97, 14-21. doi: 10.1016/j.jenvman.2011.11.002

Stoddard, R. A., Atwill, E. R., Gulland, F. M., Miller, M. A., Dabritz, H. A., Paradies, D. M., et al. (2008). Risk factors for infection with pathogenic and antimicrobial-resistant fecal bacteria in northern elephant seals in California. Public Health Rep. 123, 360-370. doi: 10.1177/003335490812300316

Tourchin, M. E., Lafferty, K. D., and Kuris, A. M. (2002). Parasites and marine invasions. Parasitology 124(Suppl.), S137-S151.

Turnbull, B. S., and Cowan, D. F. (1998). Myocardial contraction band necrosis in stranded cetaceans. J. Comp. Pathol. 118, 317-327. doi: 10.1016/s0021-9975(07) 80007-7

Van Bressem, M. F., Raga, J. A., Di Guardo, G., Jepson, P. D., Duignan, P. J., Siebert, U., et al. (2009). Emerging infectious diseases in cetaceans worldwide and the possible role of environmental stressors. Dis. Aquat. Organ. 86, 143-157. doi: 10.3354/dao02101

Van Bressem, M. F., Van Waerebeek, K., and Raga, J. A. (1999). A review of virus infections of cataceans and the potential impact of morbilliviruses, poxviruses and papillomaviruses on host population dynamics. Dis. Aquat. Organ. 38, 53-65. doi: 10.3354/dao038053

van Elk, C. E., Van De Bildt, M. W., De Jong, A. A., Osterhaus, A. D., and Kuiken, T. (2009). Herpesvirus in bottlenose dolphins (Tursiops truncatus): cultivation, epidemiology, and associated pathology. J. Wildl. Dis. 45, 895-906. doi: 10.7589/0090-3558-45.4.895

Waltzek, T. B., Cortes-Hinojosa, G., Wellehan, J. F. Jr., and Gray, G. C. (2012). Marine mammal zoonoses: a review of disease manifestations. Zoonoses Public Health 59, 521-535. doi: 10.1111/j.1863-2378.2012.01492.x

Weilgart, L. S. (2007). The impacts of anthropogenic ocean noise on cetaceans and implications for management. Can. J. Zool. 85, 1091-1116. doi: 10.1139/ z07-101

Wells, R. S., Tornero, V., Borrell, A., Aguilar, A., Rowles, T. K., Rhinehart, H. L., et al. (2005). Integrating life-history and reproductive success data to examine potential relationships with organochlorine compounds for bottlenose dolphins (Tursiops truncatus) in Sarasota Bay, Florida. Sci. Total Environ. 349, 106-119. doi: 10.1016/j.scitotenv.2005.01.010

Williams, R., Lusseau, D., and Hammond, P. S. (2006). Estimating relative energetic costs of human disturbance to killer whales (Orcinus orca). Biol. Conserv. 133, 301-311. doi: 10.1016/j.biocon.2006.06.010

Wright, A. J., Soto, N. A., Baldwin, A. L., Bateson, M., Beale, C. M., Clark, C., et al. (2007). Do marine mammals experience stress related to anthropogenic noise? Int. J. Comp. Psychol. 20, 274-316.

Yang, W. C., Chou, L. S., Jepson, P. D., Brownell, R. L. Jr., Cowan, D., Chang, P. H., et al. (2008). Unusual cetacean mortality event in Taiwan, possibly linked to naval activities. Vet. Rec. 162, 184-186. doi: 10.1136/vr.162.6.184

Yang, W. C., Pang, V. F., Jeng, C. R., Chou, L. S., and Chueh, L. L. (2006). Morbilliviral infection in a pygmy sperm whale (Kogia breviceps) from Taiwanese waters. Vet. Microbiol. 116, 69-76. doi: 10.1016/j.vetmic.2006.03.014

Yang, W.-C., Wu, B.-J., Sierra, E., Fernandez, A., Groch, K. R., Catão-Dias, J. L., et al. (2016). A simultaneous diagnosis and genotyping method for global surveillance of cetacean morbillivirus. Sci. Rep. 6:30625.

$\mathrm{Yu}, \mathrm{W}$. J. (2000). Influence of Whale-Watching Boats on Behavior of Cetaceans at Haulien, Taiwan. Master Unpublished Master thesis. Hualien: National Dong Hwa University.

Conflict of Interest: W-TL is the owner of Pangolin International Biomedical Consultant Ltd.

The remaining authors declare that the research was conducted in the absence of any commercial or financial relationships that could be construed as a potential conflict of interest.

Copyright (c) $2021 \mathrm{Li}$, Chou, Chiou, Chen and Yang. This is an open-access article distributed under the terms of the Creative Commons Attribution License (CC BY). The use, distribution or reproduction in other forums is permitted, provided the original author(s) and the copyright owner(s) are credited and that the original publication in this journal is cited, in accordance with accepted academic practice. No use, distribution or reproduction is permitted which does not comply with these terms. 